\title{
PEMBERDAYAAN WAKAF TUNAI PADA BAITUL MAAL HIDAYATULLAH DI SURABAYA DALAM BIDANG PENDIDIKAN 1 )
}

\author{
Puspita Rachman \\ Program Studi S1 Ekonomi Islam-Fakultas Ekonomi dan Bisnis-Universitas Airlangga \\ Email: puspitarach@gmail.com \\ Sri Herianingrum \\ Departemen Ekonomi Syariah-Fakultas Ekonomi dan Bisnis-Universitas Airlangga \\ Email: sriheria@yahoo.co.id
}

\begin{abstract}
:
The purpose of the research is to knowing the empowerment of cash waqf in the education sector BaitulMaalHidayatullahin Surabaya. So, that case is become the bases of the interview to knowing empowerement of cash wagf to support people welfare through education. The approach of this research is using qualitative approach. Qualitative approach is using case study method. The subject of this research is finance manager and office from BaitulMaalHidayatullah in Surabaya which will be informant and give various information which during the research.

Based on research results has showing the empowerment of cash waqf have a typical impact for education with the build of PesantrenPenghafal Al-Quran DarulHijrah. PesanternDarulHijrah not only teach the students to memorize Al-Qur'an, but also to practice the contents of Al-quran and also supported by various activity in pondokpesantren in accordance with syariah principle which will make a leader to know Al-Qur'an and AsSunnah very well.
\end{abstract}

\section{Keywords : Cash Waqf, Empowerment, Education Sector}

\section{PENDAHULUAN}

\section{Latar Belakang}

Di Indonesia, pada kenyataannya menunjukkan bahwa masih banyak harta wakaf yang dikelola secara konsumtif. Sehingga peranannya dalam menanggulangi problem sosial dan ekonomi belum maksimal. Kemajuan atau kemunduran wakaf akan sangat ditentukan oleh pengelolaan (manajemen) wakaf yang professional. Sesungguhnya ada beberapa permasalahan yang menyebabkan potensi wakaf di Indonesia belum produktif.

Salah satu dari bentuk ibadah untuk mendekatkan diri pada Allah SWT yang berkaitan dengan harta benda adalah dengan berwakaf. Mengamalkan wakaf sangat penting bagi kehidupan sosial ekonomi, kebudayaan dan keagamaan. Maka dari itu, Islam menempatkan amalan wakaf sebagai salah satu ibadah yang amat disenangi Allah SWT.

Salah satu permasalahan ini terletak di tangan nazhir selaku pemegang amanah dari waqif lorang yang berwakaf) untuk mengelola dan mengembangkan harta wakaf. Artinya, pengelolaan harta wakaf belum dilakukan secara profesional.

Sebagai lembaga, wakaf dapat digunakan sebagai salah satu formula

\footnotetext{
1) Jurnal ini merupakan bagian dari skripsi Puspita Rachman, NIM. 041211431006 yang diuji pada tanggal 2 Mei 2016
} 
Rachman, et al/Jurnal Ekonomi Syariah Teori dan Terapan Vol. 3 No. 8 Agustus 2016: 669-682; PEMBERDAYAAN WAKAF TUNAI PADA BAITUL MAAL HIDAYATULLAH DI SURABAYA DALAM BIDANG PENDIDIKAN

untuk mengembangkan bidang sosial dan ekonomi agar dapat menunjang dan meningkatkan derajat kehidupan umat Islam di Indonesia. Sebagai proses, perwakafan dapat dijadikan satu aktivitas untuk membangkitkan semangat umat Islam dan menjadikan lembaga wakaf sebagai dasar tumbuh berkembangnya gerakan sosial dan ekonomi umat Islam di Indonesia.

Harta wakaf tunai harus dikelola dan diberdayakan dengan baik dan modern. Pemberdayaan harta wakaf tunai ini sangat diperlukan dalam rangka menjalin kekuatan ekonomi umat Islam untuk meningkatkan kesejahteraan kehidupan masyarakat banyak. Tentu saja pemberdayaan ini membutuhkan kerja sama dari semua pihak dan kalangan, khususnya di bidang perbankan yang mempunyai kekuatan dana untuk memberikan pinjaman, atau lembagalembaga pihak ketiga lainnya yang beminatuntuk berkontribusi dalam proses pengembangan wakaf.

Kerja sama kemitraan ini memerlukan dukungan dan komitmen dari semua pihak seperti pemerintah, ulama, kalangan professional, cendikiawan, pengusaha, perbankan dan sebagainya sehingga potensi wakaf dapat memiliki peranan yang cukup penting dalam aktivitas ekonomi secara nasional.

Di Indonesia, kenyataan menunjukkan bahwa masih banyak harta wakaf yang dikelola secara konsumtif dan tradisional, sehingga peranannya sebagai katalisator bagi problem sosial dan ekonomi umat tidak maksimal, oleh karena itu dituntut adanya efektifitas dan efisiensi dalam pemberdayaan dana wakaf tunai oleh nazhir selaku pengelola sehingga potensi wakaf tunai akan menjadi sangat penting dan dapat dimanfaatkan secara optimal dalam menunjang program pendidikan yang dijalankan.

Nazhir wakaf tunai perlu melakukan usaha serius dan langkah terarah dalam mengambil kebijaksanan berdasarkan program kerja yang telah digariskan. Tetapi, peranan penting dan esensial dari nazhir wakaf tersebut tidaklah selamanya sesuai dengan tujuan.

Pendidikan sangat penting bagi suatu negara. Tingginya jenjang pendidikan ialah suatu esensi penting bagi produksi ekonomi dalam suatu negara. Al Ghazali membagi tingkatan kebutuhan manusia menjadi tiga tingkatan, yaitu dharuriyat, hajiyat, dan taksiniyat. Dharuriyat merupakan keharusan dan landasan dalam menegakkan kesejahteraan manusia di dunia dan akhirat yang mencakup pemeliharaan lima unsur pokok kehidupan manusia lagama, hidup, akal, keturunan dan harta). Tidak terwujudnya aspek dharuriyat dapat merusak kehidupan manusia di dunia dan akhirat secara keseluruan. Pemeliharaan akal dapat terdiri dari: 
a. Pendidikan: penyediaan lembaga pendidikan dari tingkat dasar sampai perguruan tinggi, biaya pendidikan yang rendah bahkan gratis, penyediaan alokasi dana yang tinggi untuk sektor penidikan, penyediaan sarana pendidikan yang memadai termasuk guru dan tenaga pengajar.

b. Penerangan dan kebudayaan

c. Penelitian ilmiah: pusat pengembangan kurikulum, pusat pengembangan ilmu modern, pusat penelitian, dan lain-lain. Indikator kesuksesan pembangunan ekonomi dapat dilihat dari terpenuhinya kebutuhan dasar untuk memelihara jiwa dan akal manusia. Semua elemen-elemen penunjang dari pemeliharaan jiwa dan akal adalah mutlak disediakan.

Dalam pembangunan nasional, pendidikan harus lebih berperan dalam membangun seluruh potensi manusia agar menjadi subyek yang berkembang secara optimal dan bermanfaat bagi masyarakat dan pembangunan nasional. Dalam konteks demikian, pembangunan pendidikan itu mencakup berbagai dimensi yang sangat luas yang meliputi dimensi sosial, budaya, ekonomi, dan politik.

Dalam perspektif sosial, pendidikan akan melahirkan insan-insan terpelajar yang mempunyai peranan penting dalam proses perubahan sosial di dalam masyarakat. Dalam perspektif budaya, pendidikan merupakan wahana penting dan medium yang efektif untuk mengajarkan norma, mensosialisasikan nilai, dan menanamkan etos di kalangan warga masyarakat. Dalam perspektif politik, pendidikan harus mampu mengembangkan kapasitas individu untuk menjadi warga negara yang baik, yang memiliki kesadaran akan hak dan tanggung jawab dalam kehidupan bermasyarakat, berbangsa, dan bernegara.

Pendidikan harus dapat melahirkan individu yang memiliki visi dan idealisme untuk membangun kekuatan bersama sebagai bangsa. Saat ini, generasi muda Indonesia sedang mengalami penurunan moral dan akhlak yang sangat memprihatinkan untuk keberlangsungan negara Indonesia di masa yang akan datang tetapi hal tersebut dapat diatasi dengan peningkatan kualitas pendidikan.

Atas dasar inilah, peneliti tertarik melakukan penelitian pada Baitul Maal Hidayatullah di Surabaya dengan tujuan untuk mengetahui pemberdayaan dana wakaf tunai dalam bidang pendidikan di lembaga ini serta problematika secara umum dan langkah-langkah yang ditempun BMH Surabaya dalam mengatasi problematika tersebut dengan penelitian yang berjudul Pemberdayaan Wakaf Tunai dalam Bidang Pendidikan 
Rachman, et al/Jurnal Ekonomi Syariah Teori dan Terapan Vol. 3 No. 8 Agustus 2016: 669-682; PEMBERDAYAAN WAKAF TUNAI PADA BAITUL MAAL HIDAYATULLAH DI SURABAYA DALAM BIDANG PENDIDIKAN

pada Baitul Maal Hidayatullah di Surabaya.

\section{LANDASAN TEORI}

Menurut

Hadi

(2004:3)

Pemberdayaan adalah suatu cara dengan mana rakyat, organisasi, dan komunitas diarahkan agar mampu menguasai (atau berkuasa atas) kehidupannya . Definisi pemberdayaan yang dikemukakan diatas dapat ditarik suatu kesimpulan bahwa pemberdayaan merupakan upaya untuk memampukan dan memandirikan masyarakat atau dengan kata lain adalah bagaimana menolong masyarakat untuk mampu menolong dirinya sendiri.

Menurut Samsudin pengertian wakaf, secara menyeluruh dapatdisimpulkan mengenai ruang lingkup wakaf yaitu :

a) Menahan harta untuk dikonsumsi atau dipergunakan secara pribadi;

b) Definisi wakaf ini mencakup harta, baik berupa benda bergerak, tidak bergerak, maupun uang;

C) Mengandung pengertian melestarikan harta dan menjaga keutuhannya, sehingga memungkinkan untuk dimanfaatkan secara langsung atau diambil manfaat hasilnya secara berulang-ulang;

d) Berulang-ulangnya manfaat dan kelanjutannya baik yang berlangsung lama, sebentar maupun selamanya; e) Menghasilkan manfaat langsung dari harta atau benda yang diwakafkan, mencakup juga wakaf produktif yang memberi manfaat dari hasil produksinya;

f) Mencakup jalan kebaikan umum keagamaan, social dan sebagainya, juga mencakup kebaikan khusus yang dimanfaatkan untuk kebaikan keluarga wakif;

g) Mencakup pengertian wakaf menurut fikih dan perundangundangan, bahwa wakaf tidak terjadi kecuali dengan keinginan wakif mencakup pentingnya penjagaan harta wakaf.

Menurut Fuad (2005:34) Pendidikan adalah aktivitas dan usaha manusia untuk meningkatkan kepribadiannya dengan jalan membina potensi -potensi pribadinya, yaitu rohani (pikir, karsa, rasa, cipta dan budi nurani). Pendididkan juga berarti lembaga yang bertanggungjawab menetapkan cita - cita (tujuan) pendidikan, isi, sistem dan organisasi pendidikan. Lembaga - lembaga ini meliputi keluarga, sekolah dan masyarakat.

Kesejahteraan menurut pengertian Al-Qur'an tercermin di Surga yang dihuni oleh Nabi Adam dan isterinya sesaat sebelum mereka bertugas sebagai khalifah di bumi. Kesejahteraan yang digambarkan dalam ayat inimenjamin adanya pangan, sandang, dan papan yangdiistilahkan dengan tidak kelaparan, 
Rachman, et al/Jurnal Ekonomi Syariah Teori dan Terapan Vol. 3 No. 8 Agustus 2016: 669-682; PEMBERDAYAAN WAKAF TUNAI PADA BAITUL MAAL HIDAYATULLAH DI SURABAYA DALAM BIDANG PENDIDIKAN

tidak merasadahaga, tidak telanjang, dan tidak kepanasan olehmatahari.

Kebalikan darinya adalah kehidupan yang sempit, yakni jauh dari tentram dan tenang, selalu tidak puas, dadanya sesak dan gelisah walaupun lahirnya tampak mewah, serba ada, cukup pakaian dan tempat tinggalnya. Kesejahteraan hanya diperoleh dengan penyerahandiri sepenuhnya kepada Allah Swt. Ajaran Islam mengajarkan juga tentang konsep untuk berbagi,membagi nikmat, membagi kebahagian dan ketenangantidak hanya untuk individu namun untuk seluruh umatmanusia di seluruh dunia.

Kesejahteraan dalam perspektif ekonomi Islam adalah terpenuhinya kebutuhan materi dan non materi, dunia dan diakhirat berdasarkan kesadaran pribadi dan masyarakat untuk patuh dan taat terhadap hukum yang dikehendaki oleh Allah Swt melalui petunjuk-Nya dalam Al-Qur'an, melalui contoh dalam keteladanan Rasulullah Saw, dan melalui ijtihat dan kebaikan para ulama, oleh karenanya kesejahteraan bukanlah sebuah cita-cita yang tanpa pengorbanan tetapi membutuhkan perjuangan yang terus menerus dan berkesinambungan.

Menurut Syamsuddien (1994:6668)Kesejahteraan merupakan tujuan dari ajaran Islam dalambidang ekonomi. Kesejahteraan merupakan bagian darirahmatan lil alamin yang diajarkan oleh Agama Islam ini.
Namun kesejahteraan yang dimaksudkan dalam Islam bukanlah tanpa syarat untuk mendapatkannya. Kesejahteraanakan diberikan oleh Allah SWT jika manusia melaksanakanapa yang diperintahkan-Nya dan menjauhi apa yangdilarang-Nya. Ayat-ayat Al-Qur'an yang memberikan penjelasantentang kesejahteraan ada yang secara langsung (tersurat)dan ada yang secara tidak langsung (tersirat) berkaitandengan permasalahan ekonomi. Namun demikian, penjelasandengan menggunakan dua cara ini menjadi satu pandangantentang kesejahteraan.

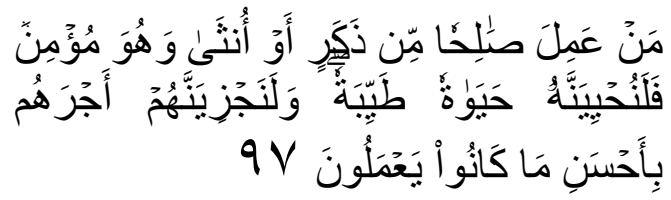

Artinya: "Barang siapa mengerjakan kebaikan, baik laki-laki maupun perempuan dalam keadaan beriman, maka pastiakan Kami berikan kepadanya kehidupan yang baik danakan Kami beri balasan dengan pahala yang lebih baik dari apa yang telah mereka kerjakan."(Qs. Al-Nahl: 97)

Proposisi dari penelitian ini adalah berdasarkan landasan teori yang telah disajikan sebelumnya maka, peneliti ini didasarkan atas proposisi yaitu pemberdayaan wakaf tunai yang dikelola oleh Baitul Maal Hidayatullah Surabaya dan dampaknya dalam bidang pendidikan di masyarakat.

\section{METODE PENELITIAN}

Penelitian ini juga menggunakan pendekatan kualitatif deskriptif. Apabila peneliti ingin mengetahui keadaan atau sesuatu mengenai apa dan bagaimana, 
Rachman, et al/Jurnal Ekonomi Syariah Teori dan Terapan Vol. 3 No. 8 Agustus 2016: 669-682; PEMBERDAYAAN WAKAF TUNAI PADA BAITUL MAAL HIDAYATULLAH DI SURABAYA DALAM BIDANG PENDIDIKAN

berapa banyak, sejauh mana, dan lainlain, maka penelitian tersebut bersifat deskriptif, dimana penelitian ini menjelaskan suatu peristiwa (Arikunto, 2002:30).

Penelitian ini bertujuan untuk menjawab rumusan masalah, yaitu "Bagaimana pemberdayaan wakaf tunai dalam bidang pendidikan di Baitul Maal Hidayatullah Surabaya?". Pertanyaan "bagaimana" sangat tepat jika menggunakan pendekatan kualitatif, karena dalam penelitian ini peneliti tidak memiliki kesempatan untuk melakukan kontrol terhadap obyek penelitian.

Strategi yang digunakan dalam penelitian ini adalah studi kasus. Rumusan masalah tersebut membutuhkan jawaban dengan kajian yang mendalam, khususnya berkaitan dengan kajian literatur serta mengutamakan bukti yang akurat melalui observasi secara langsung ke obyek penelitian yakni lembaga pengelola wakaf tunai.

Rumusan masalah tersebut menjadi acauan peneliti dalam menentukan ruang lingkup penelitian ini. Ruang lingkup penelitian terbatas pada bagaimana pemberdayaan wakaf tunai Baitul Maal Hidayatullah Surabaya dan bagaimana penyaluran dana wakaf tunai dalam bidang pendidikan untuk menunjang kualitas santri di Baitul Maal Hidayatullah Surabaya.

Penelitian ini fokus pada pemberdayaan dana wakaf tunai sebagai penunjang dalam bidang pendidikan. Dana wafak tunai dialokasikan untuk pembangunan Pesantren Darul Hijrah 1 atau setara sekolah Sekolah Menengah Pertama.

Data dalam penelitian kualitatif dibagi menjadi dua yaitu data utama dan data penunjang atau tambahan. Data utama merupakan data primer yang berasal dari hasil wawancara. Data penunjang merupakan data sekunder yang diperoleh dari suatu obyek penelitian yang berupa arsip, laporanlaporan dan dokumen-dokumen yang relevan serta kajian pustaka yang berkaitan dengan permasalahan.

Sumber dan jenis data dalam penelitian ini diperoleh dengan cara sebagai berikut:

a. Key informan (informasi utama) Key informan yang dijadikan sumber data dalam penelitian ini adalah nadzir yang dimaksudkan dalam penelitian ini adalah Baitul Maal Hidayatullah Surabaya. Obyek ini penelitian ini diharapkan mendapat informasi tentang pemberdayaan dana wakaf tunai di bidang pendidikan yang diterapkan Baitul Maal Hidayatullah Surabaya.

b. Data penunjang

Data tambahan dalam penelitian ini adalah pandangan para ulama ataupun pakar ekonomi islam tentang wakaf. Data sekunder ini diperoleh dari buku-buku tentang wakaf, jurnal, internet dan sumber-sumber lain yang relevan.

Data primer diperoleh dengan menggunakan prosedur sebagai berikut: 
Rachman, et al/Jurnal Ekonomi Syariah Teori dan Terapan Vol. 3 No. 8 Agustus 2016: 669-682; PEMBERDAYAAN WAKAF TUNAI PADA BAITUL MAAL HIDAYATULLAH DI SURABAYA DALAM BIDANG PENDIDIKAN

\section{a. Persiapan awal}

Pada tahap ini, peneliti mengurus surat ijin penelitian skripsi secara formal pada bagian akademik Fakultas Ekonomi dan Bisnis (FEB) UNAIR sebagai penunjang untuk memasuki lembaga wakaf yang ada di Surabaya. Tujuan mendatangi lembaga wakaf ini adalah untuk mendapatkan informasi mengenai proses pengumpulan dana hingga pendistribusiannya kepada para mauquf alaih secara jelas dan terperinci, mulai dari berapa banyak besar dana yang dialokasikan untuk kegiatan produktif serta berapa dan siapa saja mauquf alaih yang menerima dana tersebut, dan untuk mendapatkan informasi lain yang diperlukan untuk penelitian ini.

b. Proses pemasukan lokasi atau obyek penelitian

Pada tahap ini, penelitian segera menemui bagian SDM dari lembaga wakaf yang dituju dengan membawa surat ijin penelitian secara formal dari FEB UNAIR sebagai penunjang.

c. Saat dilokasi atau obyek penelitian Peneliti menjelaskan maksud dan tujuan penelitian kepada lembaga wakaf yang dituju, kemudian melakukan observasi secara langsung pada datadata lembaga wakaf, bagaimana penggunaan dana wakaf yang diperoleh. Peneliti juga melakukan wawancara kepada pihak lembaga wakaf untuk memperoleh data para mauquf alaih yang akan diteliti.
Hal itu tentu saja dilakukan beberapa hari secara terus menerus secara berkala sampai peneliti mendapatkan jawaban dari rumusan masalah yang telah ditentukan sebelumnya. Peneliti juga akan melakukan wawancara kepada para mauquf alaih untuk mendapatkan data yang sebenarnya, dan sesuai dengan apa yang peneliti dapatkan dari hasil wawancara kepada lembaga wakaf yang diteliti.

\section{d. Saat pengumpulan data}

Peneliti mendapatkan data dari hasil observasi secara langsung kepada pihak lembaga wakaf dan para penerima dana wakaf yang menjadi sumber penelitian. Pengambilan data dan wawancara dilakukan secara terbuka dan dengan pertanyaan yang terusmenerus berkembang setiap peneliti datang ke lokasi dimana obyek penelitian itu berada, tetapi tetap fokus dan mengarah kepada apa yang diteliti. Hasil observasi dan wawancara dari obyek penelitian akan didokumentasikan sendiri oleh peneliti.

Pada tahap validasi data penelitian ini menggunakan pengujian triangulasi. Menurut Sugiyono (2007:464) Triangulasi dalam pengujian kredibilitas diartikan sebagai pengecekan data dari berbagai sumber dan berbagai cara dengan demikian terdapat triangulasi sumber dan triangulasi teknik pengumpulan data.

1. Triangulasi Sumber 
Rachman, et al/Jurnal Ekonomi Syariah Teori dan Terapan Vol. 3 No. 8 Agustus 2016: 669-682; PEMBERDAYAAN WAKAF TUNAI PADA BAITUL MAAL HIDAYATULLAH DI SURABAYA DALAM BIDANG PENDIDIKAN

Triangulasi sumber untuk menguji kredibilitas data dilakukan dengan cara memeriksa data yang telah diperoleh melalui beberapa sumber. Dalam penelitian ini menggunakan triangulasi sumber yaitu dengan mewawancarai beberapa informan dari Pengurus Lembaga Amil Zakat Baitul Maal Hidayatullah di Surabaya dan dari Pengurus Pesantren Penghafal Al-Qur'an Darul Hijrah 1 Surabaya untuk mendapatkan data yang valid.

2. Triangulasi Teknik Triangulasi teknik untuk menguji kredibilitas data dilakukan dengan memeriksa data kepada sumber yang sama dengan teknik yang berbeda. Seperti data diperoleh dengan wawancara, lalu dicek dengan observasi serta dokumentasi. Dalam penelitian ini menggunakan triangulasi teknik yaitu dengan melakukan teknik wawancara, dilanjutkan dengan observasi dan dokumentasi sehingga data yang diperoleh dapat bersifat valid.

Teknik analisis data dalam penelitian ini adalah analisis data kualitatif, dimana analisis datanya dilakukan dengan cara non statistik, yaitu penelitian yang dilakukan dengan menggambarkan data yang diperoleh dengan kata-kata atau kalimat yang dipisahkan dalam kategori-kategori untuk memperoleh kesimpulan. Jadi, analisis data kualitatif yaitu setelah data diperoleh data diproses, dianalisis, dan dibandingkan dengan teori-teori dan keludian dievaluasi, dari hasil evaluasi tersebut akan diambil kesimpulan untuk menjawab permasalahan yang muncul.

Analisis data dalam penelitian kualitatif, dilakukan pada saat pengumpulan data berlangsung, dan setelah selesai pengumpulan data dalam periode tertentu.

\section{PEMBAHASAN}

Melalui musyawarah Nasional 1 pada tanggal 9-13 Juli 2000 di Balikpapan, Hidayatullah kemudian mengubah bentuk organisasinya menjadi organisasi kemasyarakatan (ormas) dan menyatakan diri sebagai gerakan perjuangan Islam. Di Surabaya, Hidayatullah dengan Laznas BMH tersebut merintis perjuangannya sejak sekitar tahun 1980 dengan didirikan pesantren Hidayatullah di daerah Kejawan Putih Tambak Surabaya dan Laznas BMH hingga menempati kantor yang sekarang setelah diresmikan pada tanggal 30 Agustus 2008 bertempat di Jl. Raya Mulyosari No. 938 Surabaya.

Pesantren Penghafal Al-Qur'an Darul Hijrah 1 dibangun dari dana wakaf tunai oleh Baitul Maal Hidayatullah di Surabaya. Terletak tidak jauh dari Lembaga Amil Zakat Baitul Maal Hidayatullah di Surabaya berlokasi di jalan Kejawen Putih Tambak no.110 Surabaya. BMH memiliki beberapa program untuk pemberdayaan wakaf tunai yaitu pembangunan dan/ atau perbaikan di beberapa masjid, kemudian khusus untuk 
Rachman, et al/Jurnal Ekonomi Syariah Teori dan Terapan Vol. 3 No. 8 Agustus 2016: 669-682; PEMBERDAYAAN WAKAF TUNAI PADA BAITUL MAAL HIDAYATULLAH DI SURABAYA DALAM BIDANG PENDIDIKAN

pendidikan yaitu dibangunnya Pesantren Darul Hijrah. Baitul Maal Hidayatullah di Surabaya mendayagunakan dana wakaf tunai fokus untuk pembangunan pesantren Darul Hijrah tetapi juga tetap membagikan donasi dari donatur pada BMH di wilayah lain yang membutuhkan agar dapat merealisasikan programnya.

\section{Analisis Prosedur Penyaluran Dana Wakaf} Tunai Baitul Maal Hidayatullah di Surabaya

Tim manajemen mengajukan anggaran dana untuk merealisasikan program yang sudah direncanakan. Pihak mustahiq adalah pihak luar BMH tetapi tetap satu induk dari Lembaga Ormas Hidayatullah. Tim BMH mengawasi secara berkala atas penggunaan dana yang diberikan karena hal tersebut termasuk dalam prosedur agar tercapainya pembangunan yang maksimal dan sesuai dengan harapan Baitul Maal Hidayatullah maupun harapan donatur.

Tahapan untuk penyaluran dana wakaf tunai yaitu: pembuatan proposal penghimpunan dana yang mencakup berapa besar dana yang dibutuhkan untuk melaksanakan program tersebut, dilanjutkan dengan proses penghimpunan dana. Di sisi lain melakukan survey lokasi dengan detail pada lembaga tersebut, analisa tempat, dan kelayakan mendapatkan bantuan, kemudian rapat proses pengesahan atau penyetujuan proposal, apabila proposal telah disetujui maka dapat dilakukan pencairan dana untuk melaksanakan program, dilanjutkan dengan menyusun laporan secara faktual sebagai bukti terealisasinya proposal program yang diajukan.

Penyaluran dana wakaf tunai yang dilakukan Baitul Maal Hidayatullah terus diawasi oleh pihak auditor independen dari Jakarta yang sudah ahli dalam bidangnya, pidak tersebut lepas dari BMH.

\section{Analisis Pengalokasian Dana Wakaf Tunai}

\section{Baitul Maal Hidayatullah di Surabaya}

Baitul Maal Hidayatullah memiliki program yang sudah ada kemudian mengajukan penganggaran dana, pihak yang mendayagunakan dana wakaf tunai tidak ada hubungan dengan lembaga BMH tetapi tetap satu induk dengan lembaga $\mathrm{BMH}$ serta $\mathrm{BMH}$ mengerti dan paham akan kredibilitas pihak tersebut.

BMH melakukan survey tempat untuk dokumentasi untuk mengetahui apa saja yang dibutuhkan serta dalam jangka berapa tahun akan memberikan saluran dana, apabila di tempat tersebut sudah ada donatur lain yang dapat menutup anggaran dana yang dibutuhkan tempat tersebut maka BMH akan mementingkan hal-hal yang lebih mendesak dan harus segera dibantu. Dana wakaf tunai di Baitul Maal Hidayatullah harus habis di akhir tahun karena menghindari penumpukan dana dan mempercepat penyaluran bantuan dengan tetap mempersiapkan penyaluran terbaik. Wakaf tunai dialokasikan untuk membangun pesantren tahfidz yaitu Pesantren Penghafal AlQur'an Darul Hijrah 1 yang terletak di 
Rachman, et al/Jurnal Ekonomi Syariah Teori dan Terapan Vol. 3 No. 8 Agustus 2016: 669-682; PEMBERDAYAAN WAKAF TUNAI PADA BAITUL MAAL HIDAYATULLAH DI SURABAYA DALAM BIDANG PENDIDIKAN

Surabaya, Pesantren Penghafal Al-Qur'an 2 yang terletak di Pasuruan, dan semua barang yang bermanfaat untuk dakwah. Baitul Maal Hidayatullah juga berusaha untuk mewujudkan keinginan yaitu membangun kampung muslim dengan melakukan pendekatan pada tiap individu di masyarakat terlebih dahulu, kemudian membentuk sebuah komunitas yang memiliki kegiatan yang selalu berada di jalan Allah.

Analisis Pelaksanaan pada Pengelolaan Dana Wakaf Tunai di Pesantren Penghafal Al-Quran Darul Hijrah 1

Pesantren Penghafal Al-Qur'an Darul Hijrah 1 adalah pesantren yang dibangun Baitul Maal Hidayatullah yang muridnya sebagian besar adalah dari anak yatim piatu, dan sisanya adalah dhuafa, jamaah Baitul Maal Hidayatullah Surabaya, dan dari umum yaitu anakanak yang berprestasi. Sebagaimana terdapat dalam surat An-nisa ayat 5:

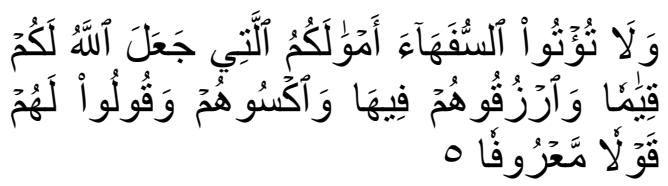

Artinya: "Dan janganlah kamu serahkan kepada orang-orang yang belum sempurna akalnya, harta (mereka yang ada dalam kekuasaanmu) yang dijadikan Allah sebagai pokok kehidupan. Berilah mereka belanja dan pakaian (dari hasil harta itu) dan ucapkanlah kepada mereka kata-kata yang baik."(Qs. An-Nisa:5)

Berdasarkan ayat diatas, dalam ajaran islam pemeliharaan anak tidaklah cukup hanya dengan nafkah lahirnya saja tanpa memperhatikan aspek pendidikan dan moralitas anak, terlebih untuk anak yatim yang tidak memiliki orang tua lagi.

Pesantren Darul Hijrah 1 memiliki beberapa program kegiatan yaitu sebagai berikut:

1. Pendidikan Al-Qur'an dengan target menghafal Al-Qur'an 30 juz selama 6 bulan pendidikan. Tidak hanya menghafal, santri diharapkan mampu memahami serta mengamalkan isi AlQur'an.

2. Pendidikan agama seperti pembelajaran fiqh, hadits, aqidah, dan bahasa arab.

3. Pendidikan formal di SMP Luqman AI Hakim agar pendidikan formalnya tidak tertinggal.

4. OSHDA (Organisasi Siswa Darul Hijrah) sebagai bentuk latihan berorganisasi bagi santri.

5. Olah fisik yang meliputi berkuda, memanah, berenang, mendaki yang dilaksanakan tiap setahun sekali, dan bela diri tifan yang mendatangkan guru dari luar pesantren serta dilaksanakan setiap hari sabtu.

6. Ekstrakulikuler seperti nasyid, olimpiade, dan memasak.

Tujuan kedepan adalah mampu mengadakan sekolah sendiri agar lebih mudah dalam menyesuaikan jadwal kegiatan murid tanpa harus mengikuti jadwal dari sekolah SMP Lukman Al-Hakim. Sejauh ini tempat sekolah untuk pendidikan formal para murid masih terlepas dari pondok pesantren. 
Rachman, et al/Jurnal Ekonomi Syariah Teori dan Terapan Vol. 3 No. 8 Agustus 2016: 669-682; PEMBERDAYAAN WAKAF TUNAI PADA BAITUL MAAL HIDAYATULLAH DI SURABAYA DALAM BIDANG PENDIDIKAN

Baitul Maal Hidayatullah memilih melalukan pembangunan pada tanah dengan harga terjangkau dan

\begin{tabular}{|l|c|c|c|}
\hline \multicolumn{1}{|c|}{ Indikator } & Informan 1 & Informan 2 & informan 3 \\
\hline $\begin{array}{l}\text { Ketersediaan Layanan } \\
\text { Pendidikan }\end{array}$ & $\sqrt{ }$ & $\sqrt{ }$ & \\
\hline $\begin{array}{l}\text { Keterjangkauan } \\
\text { Layanan Pendidikan }\end{array}$ & $\sqrt{ }$ & & $\sqrt{ }$ \\
\hline $\begin{array}{l}\text { Kualitas Layanan } \\
\text { Pendidikan }\end{array}$ & - & $\sqrt{ }$ & \\
\hline $\begin{array}{l}\text { Kesetaraan } \\
\text { Memperoleh Layanan } \\
\text { Pendidikan }\end{array}$ & $\mathrm{X}$ & $\mathrm{x}$ & $\mathrm{V}$ \\
\hline $\begin{array}{l}\text { Kepastian Memperoleh } \\
\text { Layanan Pendidikan }\end{array}$ & $\sqrt{ }$ & $\sqrt{ }$ \\
\hline
\end{tabular}

terletak ditempat yang strategis. Mulai dari pembebasan tanah, pembangunan gedung, hingga operasional lembaga tersebut diakomodir oleh BMH dengan harapan dapat mewujudkan sebuah Kampung Muslim.

Analisis Indikator Pemberdayaan Wakaf Tunai dalam Bidang Pendidikan pada Baitul Maal Hidayatullah Di Surabaya

Peneliti telah mendapatkan hasil data dari wawancara dan observasi langsung ke subyek dan obyek penelitian. Peneliti melakukan wawancara mengenai penberdayaan wakaf tunai khusus untuk pendidikan yang dilakukan oleh Lembaga Amil Zakat BMH.

Pertanyaan yang dilontarkan peneliti juga bersifat langsung dan subyektif tentang indikator-indikator yang digunakan untuk mengukur pemberdayaan wakaf tunai dalam bidang pendidikan yang dilakukan oleh Lembaga Amil Zakat BMH. Ada lima indikator pendidikan di Indonesia yakni ketersediaan, keterjangkauan, kualitas, kesetaraan dan kepastian (Publikasi.data.kemdikbud.go.id), berikut merupakan tabel rangkuman yang telah diolah peneliti dari hasil wawancara dengan informan terkait.

Berdasarkan tabel 1. dibawah terdapat lima indikator pemberdayaan pendidikan yang dilakukan Baitul Maal Hidayatullah Surabaya,

Tabel 1.

Hasil Ttriangulasi Data

Sumber: Data primer (Diolah)

Indikator ketersediaan yang dimaksudkan adalah ketersediaan layanan pendidikan yang memadai untuk menunjang kegiatan para santri. Indikator ketersediaan melihat apa saja yang disediakan Pesantren sebagai lembaga pendidikan. Baitul Maal Hidayatullah memberikan donasi wakaf uang dari para donatur untuk membangun sebuah Pesantren Penghafal Al-Qur'an yang bernama Darul Hijrah. Gedung Pesantren yang terdiri 4 lantai tersebut terdapat beberapa ruangan yaitu musholah, kamar santri atau asrama, aula, ruang makan, perpustakaan, dan kamar inap tamu. Pesantren Penghafal Al-Qur'an Darul Hijrah menerima santri dari berbagai daerah dengan kuota kurang lebih 25 santri tiap tahun ajaran baru. Kuota tersebut tetap walaupun banyak peminat yang ingin mendaftar untuk menjadi santri pada Pesantren Penghafal Al-Qur'an Darul Hijrah. 
Rachman, et al/Jurnal Ekonomi Syariah Teori dan Terapan Vol. 3 No. 8 Agustus 2016: 669-682; PEMBERDAYAAN WAKAF TUNAI PADA BAITUL MAAL HIDAYATULLAH DI SURABAYA DALAM BIDANG PENDIDIKAN

Indikator keterjangkauan meliputi daerah mana saja yang mendapatkan kesempatan untuk bisa menjadi calon siswa. Yayasan Hidayatullah memiliki jaringan khusus di beberapa wilayah di Indonesia sehingga dapat menjangkau berbagai daerah di Nusantara termasuk pada saat mencari calon santri Pesantren Darul Hijrah 1. Santri yang diterima pada Pesantren Penghafal Al-Qur'an Darul Hijrah 1 berasal dari berbagai daerah di Indonesia, tetapi tidak ada yang berasal dari Indonesia Timur seperti Papua.

Indikator kepastian adalah kepastian dalam memperoleh layanan pendidikan pada lembaga tersebut. Lembaga Amil Zakat Baitul Maal Hidayatullah menyerahkan tanggung jawab atas peningkatan kualitas para santri pada pengurus pesantren. Pesantren Darul Hijrah menjamin kepastian santri dalam memperoleh layanan pendidikan formal jenjang Sekolah Menengah Pertama dengan mewajibkan para santri bersekolah di SMP Lukman Al-Hakim, dan kepastian memperoleh layanan pendidikan agama yaitu mewajibkan para santri hafal Al-Qur'an serta paham As-Sunnah. Pada Pesantren Darul Hijrah 1, santri diwajibkan menghafal Al-Qur'an paling sedikit 15 juz, jika hafalan tidak mencapai 15 juz maka santri tidak dapat naik ke jenjang berikutnya yaitu jenjang Sekolah Menengah Atas. Akan tetapi terdapat salah satu indikator yang tidak terpenuhi yaitu indikator kesetaraan.

\section{SIMPULAN}

Berdasarkan analisis dan pembahasan yang telah dijelaskan dalam bab 4, maka dapat diperoleh simpulan sebagai berikut:

1. Dilihat dari pemberdayaan, Baitul Maal Hidayatullah di Surabaya memberdayakan dana wakaf vang khusus untuk program pendidikan. Pemberdayaan dana wakaf uang yang dilakukan Baitul Maal Hidayatullah sejauh ini masih sebatas pembangunan Pesantren Penghafal Al-Qur'an Darul Hijrah 1 yang terletak di jalan Kejawen Putih no. 110 Surabaya. Tujuan awal dari pembangunan pesantren ini adalah membentuk pemimpin yang hafal AlQur'an dan paham As-sunnah. Pembangunan Pesantren Penghafal Al-Qur'an Darul Hijrah memberikan kesempatan kepada pihak yang kurang beruntung untuk dapat bersekolah khususnya anak yatim piatu. Para santri tidak hanya diajarkan pendidikan formal namun juga pendidikan agama yang intensif agar mencapai tujuan utama dari pembangunan pesantren.

2. Dilihat dari pengelolaan Baitul Maal Hidayatullah di Surabaya memiliki beberapa program pusat yang dikhususkan di berbagai daerah dan harus didukung oleh masing-masing wilayah, seperti BMH di Surabaya yang fokus pada program pembangunan Pesantren Penghafal Al-Qur'an Darul Hijrah 1. Rapat 
perencanaan harus sesuai dengan tujuan Baitul Maal Hidayatullah. Program terdiri dari program pusat dan program daerah. Dana wakaf vang BMH memang difokuskan untuk bidang pendidikan. Tim manajemen mengajukan anggaran dana untuk merealisasikan program yang sudah direncanakan. Pihak mustahiq adalah pihak luar BMH tetapi tetap satu induk dari Yayasan Hidayatullah. Tim BMH mengawasi secara berkala atas penggunaan dana yang diberikan karena hal tersebut termasuk dalam prosedur agar tercapainya pembangunan yang maksimal dan sesuai dengan harapan Baitul Maal Hidayatullah maupun harapan donatur.

Saran yang dapat diberikan berdasarkan hasil analisis dan temuan dalam penelitian ini adalah:

1. Bagi Baitul Maal Hidayatullah

Diharapkan Baitul Maal Hidayatullah lebih mengembangkan dan memperluas program bantuan, khususnya untuk bidang pendidikan. Terutama untuk anak-anak yang kurang mampu, mengingat angka anak putus sekolah karena tidak ada biaya di Indonesia masih tinggi.

2. Bagi Lembaga Pendidikan

Diharapkan tiap lembaga pendidikan lebih memaksimalkan pengajaran agar mempersiapkan generasi yang siap menghadapi persaingan global namun tetap berjalan di jalan Allah SWT.

3. Bagi Peneliti Selanjutnya

Diharapkan adanya penelitian selanjutnya dengan pembahasan yang lebih mendalam mengkaji mengenai pemberdayaan dana wakaf tunai khususnya pada bidang pendidikan.

\section{DAFTAR PUSTAKA}

Adi, Isbandi Rukminto. 2013. Intervensi Komunitas dan Pengembangan Masyarakat sebagai Upaya Pemberdayaan Masyarakat. Jakarta. PT Raja Grafindo Persada.

Adi, Isbandi Rukmonto. 2013. Intervensi Komunitas \& Pengembangan Masyarakat Sebagai Upaya Pemberdayaan Masyarakat. Jakarta: PT Raja Grafindo Persada

Ahmadi, Abu. Supriyono Widodo. 2003. Psikologi Belajar. Jakarta: Rineka Cipta

Arif, Syafrudin. 2010. Wakaf Tunai Sebagai Alternatif Mekanisme Redistribusi Keuangan Islam. Jurnal Ekonomi Islam, Volume IV, no 1 (Juli)

Arikunto. 2002. Prosedur Penelitian Suatu Pendekatan Praktek. Jakarta: PT Rineka Cipta

Departemen Agama Rl. 2003.Pola Pembinaan Lembaga Pengelola Zakat di Indonesia

Direktorat Pemberdayaan Wakaf. 2006. Pedoman Pengelolaan WakafTunai. Jakarta

Fahrudin, Adi. 2012. Pengantar Kesejahteraan Sosial. Bandung: Refika Aditama

Gunawan, Sumodiningrat. 1999 Pemberdayaan Masyarakat dan Jaring Pengaman Sosial. Jakarta : Gramedia

Hadi, Agus Purbathin. Tanpa Tahun. Konsep Pemberdayaan, Partisipasi dan Kelembagaan dalam Pembangunan.Yayasan 
Agribisnis/Pusat Pengembangan Masyarakat Agrikarya (PPMA)

Hikmat, Harry. $2010 . \quad$ Strategi Pemberdayaan Masyarakat. Bandung. Humaniora Utama Press

Hikmat, Harry. 2010.Strategi Pemberdayaan Masyarakat. Bandung:Humaniora Utama Press

Ihsan, Fuad. 2005. Dasar-dasar Kependidikan.jakarta: PT Asdi Mahasatya

Kementrian Agama Republik Indonesia. 2013. Panduan Pengelolaan Wakaf Tunai.www.simbi.kemenag.go.id. Diakses tanggal 28 November 2015.

Maisyaroh. 2010. Manajemen Dana Wakaf Tunai untuk Pengembangan Lembaga Pendidikan Islam (Studi pada Baitul Maal Hidayatullah (BMH) Cabang Malang). Fakultas Ekonomis Universitas Islam Negeri Maulana Malik Ibrahim Malang

Nasution, Mustafa Edwin \& Uswatun Hasanah (Editor). 2005. Wakaf Tunai Inovasi Finansial Islam, Peluang dan Tantangan dalam Mewujudkan Kesejahteraan Umat. Jakarta. PKTTI-UI

Poerwadarminto, W.J.S. 1999.Kamus Umum Bahasa Indonesia. Jakarta: Balai Pustaka

Qahaaf, Mundzir. 2005. Manajemen Wakaf Produktif. Jakarta. Penerbit Khalifa

Samsudin. 2011. Peranan Nadzir dalam Pengelolaan dan Pengembangan Tanah Wakaf pada Yayasan Pendidikan Islam At-Taqwa Kelurahan Penanggungan Kecamatan Pinang Kota Tangerang. Fakultas Syariah dan Hukum Universitas Islam Negeri Syarif Hidayatullah Jakarta

Sugiyono. 2008. Memahami Penelitian Kualitatif. Jakarta. CV Alfabeta

Syamsuddien, Darsyaf Ibnu. 1994.Prototype Negeri Yang Damai. Surabaya: Media Idaman Press

Tim Dirjen Bimas Islam. 2007. Pedoman Pengelolaan Wakaf Tunai. Jakarta. Penerbit Direktorat Pemberdayaan Wakaf

Tirtarahardja, Umar. dkk. 2005. PengantarPendidikan. Jakarta: PT RinekaCipta
Usman, Suparman. 1994. Hukum Perwakafan di Indonesia. Jakarta. Penerbit Darul Ulum Press

Utami, Anisa Fitria \& Munawar Ismail. 2014. Implementasi Pengelolaan Wakaf Tunai (Studi pada Baitul Maal Hidayatullah dan Yayasan Dana Sosial Al-Falah). Fakultas Ekonomi dan Bisnis Universitas Brawijaya

Wadjdy, Farid \& Mursyid. 2007. Wakaf dan Kesejahteraan Umat: Filantropi Islam yang Hampir Terlupakan. Yogyakarta. Penerbit Pustaka Pelajar

http://publikasi.data.kemdikbud.go.id/upl oadDir/isi_78A0AAC9-96B9-467F-B071B9AFFF132404_.pdf (diakses pada 10 April 2016, 01.11 WIB) 